\title{
SERGIJ Y. KONDRATYUK - A 60TH BIRTHDAY TRIBUTE
}

\author{
I. Kärnefelt ${ }^{1}$, L. LőKös ${ }^{2}$, M. R. D. SeAwARD ${ }^{3}$, A. Thell ${ }^{1 *}$ and N. TheLL ${ }^{4}$ \\ ${ }^{1}$ Biological Museum, Lund University, Box 117, 22100 Lund, Sweden \\ E-mails: ingvar.karnefelt@biol.lu.se, *arne.thell@biol.lu.se \\ ${ }^{2}$ Department of Botany, Hungarian Natural History Museum \\ H-1431 Budapest, Pf. 137, Hungary; E-mail: lokos.laszlo@nhmus.hu \\ ${ }^{3}$ School of Archaeological \& Forensic Sciences, University of Bradford, Bradford BD7 1DP, UK \\ E-mail:m.r.d.seaward@bradford.ac.uk \\ ${ }^{4}$ School of Social Work, Lund University, Box 117, 22100 Lund, Sweden \\ E-mail: nataliya.thell@soch.lu.se
}

On 17 May 2019 the Ukrainian lichenologist Sergij (Sergey) Kondratyuk celebrates his 60th birthday. Sergij was born in the former Ukrainian Soviet Socialistic Republic (now Ukraine) in the town Ulianivka (now Blagovishchenske). He was the second child, after his sister Vira, of Yakiv and Anna Kondratyuk (born as Rusavska). Sergij's middle, patronymic, name is Yakovich from his father's name Yakiv.

Sergij's interest in biology was triggered by his grandfather Ivan $\mathrm{Ru}-$ savsky who luckily escaped execution by Nazi Germans in World War II and worked afterwards as a gardener on a collective farm and as deacon in a local church. As a man of great kindness and wisdom, he was the first mentor of Sergij, who much later in life honoured him with the generic name Rusavskia for the Xanthoria elegans group (Hertel 2012). Already at secondary school Sergij showed deep interest and distinguished skills in biology, several times participating in biology competitions (Olympiads) at the highest level between representatives from different Soviet republics, and winning first and third prizes on different occasions. After school, he moved to Kiev to study at the Biological Faculty of the Taras Shevchenko National University, from where he graduated in 1981 with a diploma work entitled 'Lichens of Kaniv State Nature Reserve' supervised by Nadiya Massjuk in the Department of Lower Plants. Nadiya Massjuk and later Oleg Blum both inspired Sergij to choose lichenology as his specialisation.

In 1981 Sergij was enrolled as a postgraduate student in the Department of Algology and Lichenology at the M. H. Kholodny Institute of Botany in Kiev, a research institute within the National Academy of Science of Ukraine, to which he has been affiliated ever since. In line with the two-doctoral-level system, characteristic of the former Soviet Union and some post-Soviet countries, including Ukraine, Sergij defended two doctoral dissertations. He earned the degrees of Candidate of Science (equivalent to a PhD) in 1985 for the thesis entitled 'Lichens of Priednieper Height' supervised by Oleg Blum, and Doctor 
of Science (comparable to Habilitation) in 1996 for the thesis 'Lichen flora of Ukrainian Plains and its analysis'. Since then he has supervised twelve and three theses, respectively, for Candidate of Science and Doctor of Science, including three INTAS ${ }^{1} \mathrm{PhD}$ studentships and one Alexander von Humboldt Fellowship; his post-graduate students include Lyudmyla Dymytrova, Nataliya Fedorenko, Olga Nadyeina and Oleksii Redchenko (e.g. Fedorenko et al. 2012). Since 2006, Sergij has the academic title of Professor.

Sergij's international career began in 1993 with a one-month stay hosted by the legendary Josef Poelt (1924-1995) at the Institute of Botany in Graz, Austria (Kondratyuk and Poelt 1997). Shortly afterwards, in 1993-1994, he visited David Galloway at the Natural History Museum in London, where he studied lichenicolous fungi associated with Lobariaceae and Stictaceae, the taxonomy of which was revised with David Hawksworth and Brian Coppins (e.g. Coppins and Kondratyuk 1995).

In 1995-2009 Sergij frequently visited the Botanical Museum of Lund University where he had a highly productive partnership with Ingvar Kärnefelt (Figs 1-2). Together they studied the large lichen family Teloschistaceae on a worldwide basis, using their collections from several field trips, including

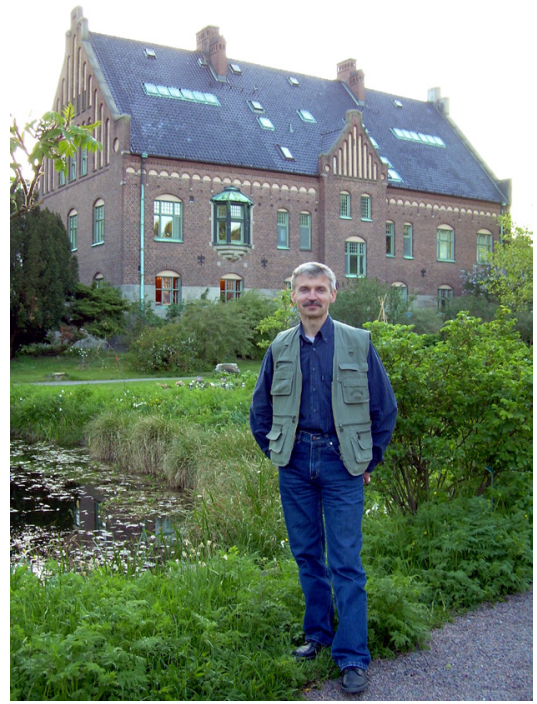

Fig. 1. Sergij Kondratyuk outside the Botanical Museum in Lund in 2008 during one of his many visits as guest researcher there those from Australia in 2003 and 2004, as well as extensive herbarium material. Ingvar and Sergij, occasionally with colleagues, described more than 60 species within the family Teloschistaceae distrib-

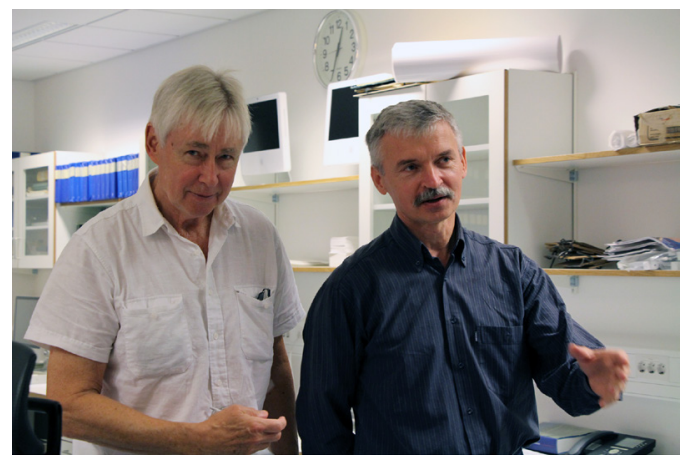

Fig. 2. Ingvar Kärnefelt and Sergij Kondratyuk in 2014. They started a successful cooperation in the early 1990s, which is still ongoing

${ }^{1}$ International Association for the promotion of co-operation with scientists from the New Independent States of the former Soviet Union. 
uted mainly in the Southern Hemisphere (e.g. Kärnefelt and Kondratyuk 2004, Kondratyuk and Kärnefelt 1997, Kondratyuk et al. 2009).

After Ingvar's retirement in 2011, Sergij cooperated with prof. Jae-Seoun Hur at the Korean Lichen Research Institute (KoLRI), Sunchon National University, the Republic of Korea. There Sergij often worked together with his close friend, the Hungarian lichenologist László Lőkös, as they recorded the lichen flora of South Korea. They described a large number of new genera and species in the Lecanoraceae, Physciaceae and Ramalinaceae and more than 100 species new to science. The results were mainly published as a series entitled 'New and noteworthy lichen-forming and lichenicolous fungi I-VIII' in Acta Botanica Hungarica in 2013-2019. During his collaboration with the Korean Lichen Research Institute, a new taxonomy for the Teloschistaceae, including more than 40 new genera and 50 new species, was determined, based often on three-gene phylogenies (Kondratyuk et al. 2013, 2014). Sergij is a strong advocate for a narrow genus concept and therefore his taxonomy is not accepted by all lichenologists.

To date, Sergij has written more than 400 scientific publications (including 25 monographs), half of which are in English; his work follows an early tradition of naming plants after colleagues and friends, such as Josefpoeltia, Gallowayella, Kaernefia, Jackelixia, Jasonhuria, Loekoesia, Gintarasiella, Massjukiella, Olegblumia,

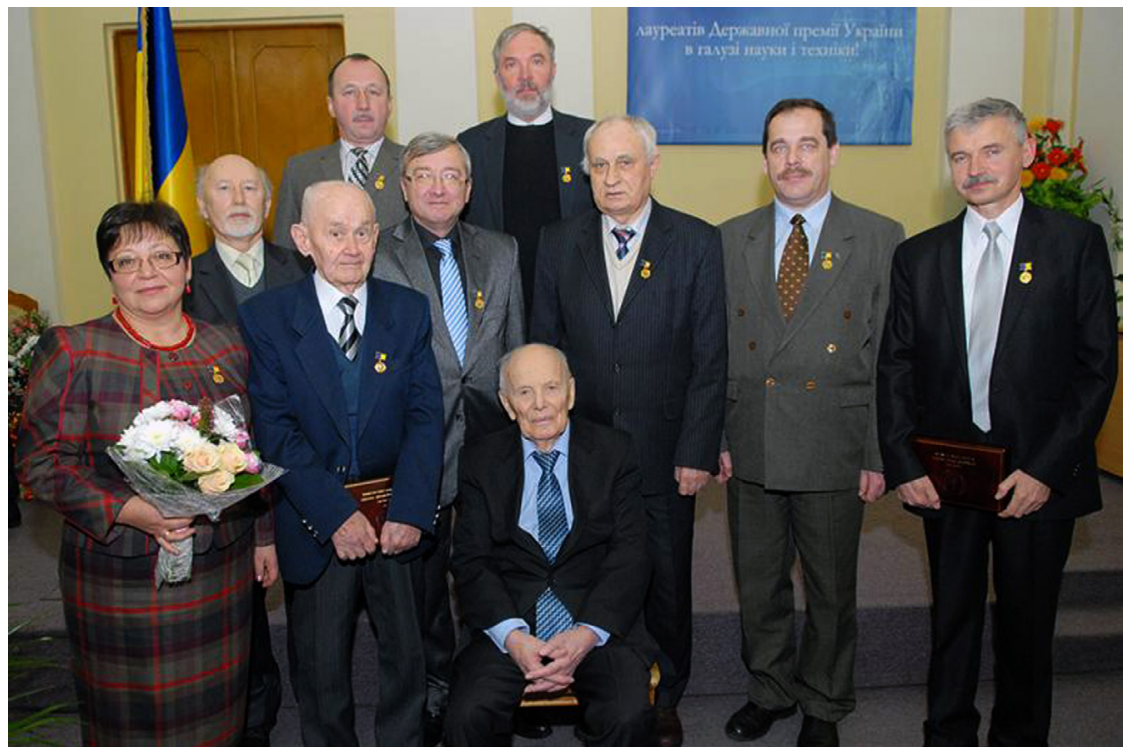

Fig. 3. Sergij Kondratyuk receives the State Award of Ukraine in the field of science and technology from the President of National Academy of Sciences of Ukraine, Academician B. Ye. Paton (sitting in the centre), in 2014. The first row from left to right: G. G. Minicheva, Y. P. Didukh, Y. P. Zaytsev, B. G. Alexandrov, O. B. Blum, I. F. Buksha, S. Y. Kondratyuk. The second row: Y. G. Tyutyunnyk, S. A. Afanasyev 
Coppinsiella and Seawardiella, as well as other names proposed for monophyletic clades in the Teloschistaceae and other families of the Lecanorales.

For his distinguished work, Sergij has received several important awards, such as the M. H. Kholodny Award of National Academy of Sciences (NAS) of Ukraine in 2013, the highest prize in the field of biological sciences in the country, as well as the State Award in the field of science and technology in 2014 (Fig. 3). Interestingly, the latter was granted not for studying taxonomy, but for elaborating methods of bioindication and monitoring of the environment of Ukraine. He received this prize as a member of a research group, which included Oleg Blum. Sergij mapped air pollution in cities and areas in the vicinity of large industries, as well as studied lichens as indicators of oldgrowth forests. Since 2018 Sergij has been a member of the Scientific Council of the National Research Foundation of Ukraine.

Sergij is widely recognised for his enormous knowledge and output, and is greatly appreciated among colleagues, friends and relatives. We wish him all the best for his birthday and many more years as a dedicated lichenologist.

\section{REFERENCES}

Coppins, B. and Kondratyuk, S. Y. (1995): Stygiomyces and Pseudonitschkia: two new genera of lichenicolous fungi. - Edinburgh J. Bot. 52(2): 229-236. https://doi.org/10.1017 /s0960428600000998

Fedorenko, N. M., Stenroos, S., Thell, A., Kärnefelt, I., Elix, J. A., Hur, J.-S. and Kondratyuk, S. Y. (2012): Molecular phylogeny of xanthorioid lichens (Teloschistaceae, Ascomycota), with notes on their morphology. - Bibl. Lichenol. 108: 45-64.

Hertel, H. (2012): Gattungseponyme bei Flechten und lichenicolen Pilzen. - Bibl. Lichenol. 107: 1-157.

Kärnefelt, I. and Kondratyuk, S. Y. (2004): Contributions to the lichen genus Caloplaca (Teloschistaceae) from Australia. - Bibl. Lichenol. 88: 255-265.

Kondratyuk, S. Y. and Kärnefelt, I. (1997): Josefpoeltia and Xanthomendoza, two new genera in the Teloschistaceae (lichenized Ascomycotina). - Bibl. Lichenol. 68: 19-44.

Kondratyuk, S. and Poelt, J. (1997): Two new Asian Xanthoria species (Teloschistaceae, lichenized Ascomycotina). - Lichenologist 29: 173-190. https://doi.org/10.1017 /s0024282997000200

Kondratyuk, S. Y., Kärnefelt, I., Elix, J. A. and Thell, A. (2009): Contributions to the Teloschistaceae, with particular reference to the Southern Hemisphere. - Bibl. Lichenol. 100: 207-282.

Kondratyuk, S. Y., Lőkös, L., Tschabanenko, S., Haji-Moniri, M., Farkas, E., Wang, X. Y., Oh, S.-O. and Hur, J.-S. (2013): New and noteworthy lichen-forming and lichenicolous fungi. - Acta Bot. Hung. 55(3-4): 275-349. https://doi.org/10.1556/abot.55.2013.3-4.9

Kondratyuk, S. Y., Kärnefelt, I., Thell, A., Elix, J. A., Kim, J., Jeong, M.-H., Yu, N.-N., Kondratiuk, A. and Hur, J.-S. (2014): A revised taxonomy for the subfamily Xanthorioideae (Teloschistaceae, Ascomycota) based on molecular phylogeny. - Acta Bot. Hung. 56(1-2): 141-178. https://doi.org/10.1556/ABot.56.2014.1-2.12 